\title{
Causes of Gender Differences in Accounting Performance: Students' Perspective
}

\author{
Lillian Wally-Dima $^{1} \&$ Christian J. Mbekomize ${ }^{1}$ \\ ${ }^{1}$ Faculty of Business, University of Botswana, Gaborone, Botswana \\ Correspondence: Lillian Wally-Dima, Faculty of Business, University of Botswana, Private Bag 00701, \\ Gaborone, Botswana. E-mail: dimalb@mopipi.ub.bw
}

\author{
Received: July 24, 2013 Accepted: August 16, 2013 Online Published: September 26, 2013 \\ doi:10.5539/ies.v6n10p13 URL: http://dx.doi.org/10.5539/ies.v6n10p13
}

\begin{abstract}
This study employs the survey method to investigate the factors that cause academic differences between female and male students at the largest university in Botswana. The population of this research was the students of the last three years of the 4 year Bachelor of Accountancy degree programme at the University of Botswana. Anchored on the prior studies' indications that female students outperform their male counterparts in accounting examinations, the current study sought the views of the respondents on factors responsible for this phenomenon and their suggestions on how the gap may be bridged. This study revealed that the key factor explaining academic performance is individual's commitment and right attitude towards accounting studies. Respondents believe that female students perform better because they work harder and have better study ethics. Females attend more classes and tutorials, seek guidance on their studies from lecturers and participate more in class discussions than their male counterparts. Male students perform poorly because they lack enthusiasm towards studies and fail to balance social life and academic work while at school. The implications of this study are that male students need to re-examine their attitude towards education, class attendance and participation in academic activities in order to improve their grades. The society and the educational institutions need to become more vigilant in ensuring that males remain focused on positive learning while in school.
\end{abstract}

Keywords: academic performance, accounting students, female students, gender, male students, University of Botswana

\section{Introduction}

\subsection{Introducing the Study}

Numerous studies have identified gender as one of the factors that explain academic performance (e.g. Bagamery, Lasik \& Nixon, 2005; Black \& Duhon, 2003; Gracia \& Jenkins, 2002). However, research results regarding which gender group performs better than the other and which factors explain the performance gap between genders have not yielded conclusive results. Traditionally, males' academic achievement was considered superior to that of females especially in mathematics and sciences because of higher levels of innate spatial ability (Benbow \& Stanley, 1980). At the same time, females' performance was placed above their male counterparts in language because of their greater verbal and reasoning abilities (Wilberg \& Lynn, 1999). However, Estronaut (1999) highlighted that studies that have found a gap between men and women's cognitive abilities have also found much more overlap. They observed that a man can grasp the skills of language just as well as a female. Similarly, many women excel in spatial skills. These observations point to the underlying complexity of the factors explaining the gender differences in education attainment and this is what has prompted the current study.

The current thinking is that gender difference in academic performance is not solely attributed to innate differences in males and females. But there are other numerous factors influencing educational ability, including, but not limited to, economic, cultural, social, and differences in educational systems and techniques (Gallagher, 2001). Factors which have been linked with accounting attainment at tertiary level include entry qualification and general ability (Jackling \& Anderson, 1998), prior accounting knowledge (Balwin \& Howe, 1982; Bergin 1983; Mitchell, 1988); class size, attributes of the teacher and complexity of the course (Naser \& Peel, 1998) and age, tuition and study material (Roos, 2009). Despite the complexity of factors influencing intellectual achievement, a number of studies are pointing to the evidence that gender is associated with academic 
performance and females are increasingly outperforming males even in the subjects which were traditionally dominated by males (Dayioglu \& Turut-Asik, 2004, Gallagher, 2001, University Council and General Board, 2001).

The current study is an expansion of research of Wally-Dima and Mbekomize (2010) who found that female students were outperforming males in accounting examinations at the University of Botswana. The authors analyzed the raw grades of students across five core courses taken by accounting students in a single semester and found that females outperformed males in four courses and more women obtained highest grades while more men scored lowest grade. On the premises that females are performing better than males, this study attempts to determine from accounting students at the major University in Botswana what could be behind female students' superior academic achievement.

\subsection{Justification of the Study}

Not many studies that have examined factors that influence gender academic achievement have sought the views of students. Most of them have analysed the past and current academic results of students and attempted to deduce the factors which could be causing a certain gender group to outperform the other. This study seeks the opinions of students as to what could be the reasons of female students performing better than their male counterparts at tertiary level. The results of the study may enlighten the accounting educators and career counsellors on what is required to effectively educate both genders.

We also need to understand gender differences in accounting performance so that early measures may be taken to avoid gender imbalances in education that can result in low economic growth and increase in social unrest (Lagerlof, 1999). Pekkarinen (2012) argues that "widening gender gap in education combined with recent wage and employment polarization will likely lead to widening inequalities and is linked to declining male labour force participation". Poor performance of either sex is not good for the economy and society. While for females poorer educational attainment is associated with early-marriages, infant mortality rates and poor health (OECD Report, 2011), for males it is linked with violent crime resulting in filling the prisons and overburdening the taxpayer (Reddock, 2009).

\subsection{Objectives of the Study}

1) To establish from accounting students the factors that cause females to outperform males in accounting.

2) To establish from accounting students what should be done to bring the academic performance between genders at par.

3) To determine whether there are differences between genders' views regarding factors causing females to do better than males.

4) To determine whether there are differences among the years of study regarding factors causing females to do better than males.

\section{Prior Research}

Factors contributing to the gender academic performances differences are many and complex and have been classified in various groups such as biological, innate, out of school and inside school factors.

\subsection{Biological Differences}

In the early stages of investigations into gender academic achievement gap, biological differences between males and females and childhood socialisation were identified as the major contributing factors. Some studies suggested that gender differences in behaviour, skills and cognitive abilities were determined by biological factors such as brain size, hormones and genetics. For example, Colom and Lynn (2004) reported that males have larger average brain sizes than females and therefore, would be expected to have higher average IQs. Kimura and Hampson (1994) asserted that fluctuations in testosterone in males and oestrogen in females were correlated with performance. On the contrary, Mackintosh (1998) revealed that there is no sex difference in general intelligence as measured by Progressive Matrices.

\subsection{Innate Differences}

A good number of researchers have attributed academic achievement to personal aptitude and effort put in school work (Carbonaro, 2005; Eskew\&Faley, 1988). Wilberg and Lynn (1999) concluded that females outperformed males in history because they tend to work more conscientiously and have a stronger work ethic than males and they tend to have better language abilities including essay writing skills, vocabulary and word 
fluency. Other researchers attributed superior performance of females to better study skills, working harder and a more frequent class attendance than male students (Leonard \& Jiang, 1999; Wainer \& Steinberg, 1992).

\subsection{Out of School Factors (Social, Culture)}

Under gender theory, it is argued that males and females come into educational systems with different sets of behaviours, attitudes and values which are a result of childhood socialisation. As a child is born into a certain society is raised in a culture that has already divided social responsibilities into masculine roles and feminine roles. This segregation of responsibilities serves to generate masculine and feminine cultural identities which tend to influence behaviour, values and attitude of that child which in turn affect his or her future academic achievement. Gender stereotypes in most societies carry the belief that the appropriate behaviour for boys is to be more aggressive and for girls is to be more passive. Females are to remain home and take care of children and carry out household duties while men go out to seek employment to feed the family. These social cultural stereotypes tend to shape the intellectual achievement. For example, Steele (1997) argued that low expectations of teachers, family and societal gender roles in which mathematics was seen as unfeminine could reduce a woman's sense of good prospects in the subject.

A recent study conducted by Hoffman, Gneezy, and List, (2011) in two Indian tribes which are substantially alike except how they treat women, revealed once again the effect of culture on academic attainment. The study tested the ability of students in solving a spatial puzzle in less than 30 seconds. Hoffman and co-authors found that among the patrilineal tribe of Karbi, men were $36 \%$ faster than women in solving the four-piece spatial puzzle. However, among the matrilineal tribe of Khasi, men were not faster than women.

On the other hand, Wilkinson (1994) had argued that remarkable improvement in females' educational performance was attributed to what is termed "gender quake" which brought fundamental changes in attitudes towards female role in society. Harding (1986) asserted that feminism itself was responsible for bringing about radical changes in the ways girls perceived themselves, where they could no longer perceive their identify in mainly domestic terms but rather as much as workers as homemakers. Warrington, Younger and Williams (2000) revealed that because of "macho" male culture boys were more likely than girls to be ridiculed by their peers for working hard at school, and frequently resorted to "laddish" behaviour such as challenging authority, drawing attention to themselves and pretending not to care about school work in order to gain acceptance from their peer group.

Gallagher (2001) holds the view that boys and girls display different academic performance not because they differ in their physical, emotional and intellectual development but rather due to some social and cultural factors. Gallagher cites these factors to include students' familiarity with subjects, changes of career aspiration, gendered perceptions of specific subjects, presentational styles of boys and girls, and teachers' expectations.

\subsection{Inside School Explanations}

Gibb, Fergusson and Horwood (2008) observed that the pervasive theme on discourses of the origins of gender performance gap is that gender differences in educational achievement are largely a reflection of gender differences in classroom behaviour. Proponents of inside school factors as contributors to gender performance differences attribute male educational underperformance to schools adopting learning and assessment procedures that are better suited to females than to males. Delamont (1999) identified the commonly cited ways in which schooling is considered to be feminised to include: school and classroom regimes that favour females; a lack of male teacher to act as academic role models for boys; a lack of toughness in discipline; a rejection of competition; and a bias towards feminism in curriculum materials. The work of Chung and Monroe (1998) which investigated the effect of different information processing styles of female and male students on the learning outcome, found that male students were hypothesis-confirming and female students were not. They concluded that this may disadvantage male students who tend to consider only confirming information and disregard disconfirming information if not considered by accounting educators in delivering course material and setting assessment items.

The UK study commissioned by the Joint Committee of Academic Performance of the University Council and General Board (2001) investigated the indicators of academic performance and concluded that factors explaining the variation in academic success are complex. The study however identified the largest source of variation in attainment to be the subject studied and gender. The study also highlighted that men and women have different attitudes towards examinations. The study further argues that while women tend to see the examination as an opportunity to increase their understanding and to focus on the subject area 'in it self' men tend to be alert to performance aspects of the examination and to tailor their intellectual development to public success. With these attitudes women prepare for examinations by working hard to show the extent of their understanding while men prepare for examinations by combining work with examination techniques in order to produce excellent 
performance. According to the study, these different approaches appear to be suitable for different subjects and may produce differing gender academic performance. For example, mathematics, engineering and physics favour instrumental approach mostly used by men and chemistry promotes conceptual understanding favoured by women.

Despite the complexity of factors explaining variations in academic performance the UK study identified many instances of good practice which can benefit all students. These include a match between student motivation and methods of learning with the teaching approach within the subject; a recognition of students' prior experiences which is reflected in both the content and the approach to teaching in the first year; a welcoming environment which makes the transition from school to university easier; a clear understanding on the part of the students about what is expected of them and what constitutes 'excellence'; and clear and constructive feedback through the supervision system and help with focusing one's efforts.

\subsection{Tertiary Level Accounting Education Performance}

The studies in the accounting performance of male and female gender at tertiary level have yielded mixed results although the main theme among them appears to be that females outperform males. The studies by Fraser, Lyttle and Stolle (1978), Lipe (1989), Mutchler, Turner, and Williams (1987) and Tyson (1989) concluded that generally female students outperform their male counterparts. Mutchler et al (1987) advanced four reasons why female students have superior performance than male students. They were of the view that females may feel driven to outperform males students in order to break into what was traditionally considered male occupation; females may be more success driven and career motivated than males; females may have a greater quantitative aptitude than males; and instructor may perceive female students as being more outstanding than males and hence tend to favour them in some ways. The longitudinal study by Sheard (2009) found that female students had better grades than their males counter parts and showed more commitment and control over demands of their programme.

Okafor and Egbon (2011) examined two accounting courses' grades of first year university students in Nigeria and concluded that there was no significant difference between academic performance of male and female. They however found that males' mean performance in both courses was higher than that of their female counterparts. The study by Gracia and Jenkins (2003) examined the second and final year accounting and finance students' performance at a Welsh university. The authors found that at second year level, gender was positively associated with performance whilst age was negatively associated. However, these findings were not repeated in the final year.

While Brahmasrene and Whitten (2001) put male students ahead of female students in the likelihood of passing CPA examination, Ross (2009) found that female students tended to outperform male students in CIMA examinations in South Africa.

\section{Research Method}

The population of this exploratory research was the students of last three years of the 4 year Bachelor of Accountancy degree programme at the University of Botswana totalling 660 in academic year 2011/2012. The first year students were excluded from the study because they were not considered to posses enough knowledge of factors impacting the learning and academic performance at tertiary level because they had just started. The convenient sample for the study was purposely identified on the basis of who happened to be in the class at the time of administering the questionnaires. The questionnaires were administered to students attending classes of Accounting for Manufacturing and Alternative Entities (ACC206), Management Accounting Applications (ACC303) and Financial Accounting IV (ACC403).The purpose of the study was explained to students before they were requested to complete the questionnaire in class.

The questionnaires comprised of six questions three of which sought respondents' demographic data. The one main question was close-ended seeking students' agreement level to the 14 factors which were found in the literature being the possible contributors to females' better performance (refer to Table 2). The questions were on a five-point Likert scale ranging from strongly agree on the upper end to strongly disagree on the lower end. One of the two open-ended questions, sought students' views on factors responsible for females' better performance in accounting subjects while the other solicited students' suggestions on how the gap existing between females' and males' academic achievement may be bridged.

\subsection{Data Analysis}

Data was analysed using the Statistical Package for Social Sciences (SPSS). Descriptive statistics were used to analyse respondents' demographic data and the students' views regarding the factors that could be influencing 
females' superior academic performance in accounting examinations. Independent $\mathrm{T}$ tests were used to compare means of two gender groups whereas ANOVA was employed to compare the means of three years of study.

\section{Results}

\subsection{Demographic Data}

All 419 questionnaires distributed were returned and 418 of them were usable. Table I that summarises the demographic data shows that respondents to the questionnaires were 269 (64\%) females and $149(36 \%)$ males. This was a true reflection of actual gender mix in the programme under study where the females are more than males in number. The University of Botswana statistics reveal that while females account for $55 \%$ of total student enrolment at University level, they account for $63 \%$ of enrolment in the Faculty of Business where the study was conducted.

Table 1. Characteristics of respondents

\begin{tabular}{lllll}
\hline & Gender & & Total & \\
\hline Characteristics & Females & Males & Total & $\%$ \\
& 269 & 149 & 418 & 100.0 \\
& Age group & & & \\
Below 18 & 0 & 2 & 2 & 0.5 \\
$18<25$ & 228 & 128 & 356 & 85.2 \\
$25<30$ & 18 & 13 & 31 & 7.4 \\
$30<35$ & 10 & 4 & 14 & 3.3 \\
Above 35 & 13 & 2 & 15 & 3.6 \\
Total & 269 & 149 & 418 & 100.0 \\
& Year of Study & & & \\
Year 2 & 88 & 47 & 135 & 32.3 \\
Year 3 & 78 & 48 & 126 & 30.1 \\
Year 4 & 103 & 54 & 157 & 37.6 \\
Total & 269 & 149 & 418 & 100.0 \\
\hline
\end{tabular}

Tables 1 also reflects that the majority of respondents were in the age group of between 18 and 25 years and respondents from year 4 were slightly higher in number than those from year 2 and 3 who were almost the same, around $30 \%$ each.

\subsection{Overall Students' Views}

Table 2 depicts the students' opinions regarding factors contributing to females' better performance than males in accounting examination. The startling result on this area was that on all the variables except one, students who picked neutral option were the largest number of all the alternatives available. Students agreed to only 5 out of 14 factors presented to them as contributors to the females' superior performance. The majority of respondents (79\%) with a mean score of 4.17 out of 5 consented to the suggestion that female students have better academic achievement because they attend more classes and tutorials than their male counter parts. This finding is in agreement with Wainer and Steinberg (1992) who found that women performed better than men because of their more frequent class attendance. Almost two thirds of respondents $(60 \%)$ with a mean score of 3.76 agreed that females' superior performance in accounting subjects can be attributed to their agility to seek guidance from lecturers about how to focus their energies to achieve excellent grades than male students. The paradox is, if students are aware that attending classes and going for consultation are crucial factors for academic success why do some students choose not to go. 
Table 2. Students' opinions on factors contributing to females' superior performance

\begin{tabular}{|c|c|c|c|c|c|c|c|c|c|}
\hline Factors & 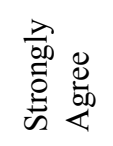 & $\frac{8}{8}$ & $\begin{array}{l}\bar{\pi} \\
\stackrel{\Xi}{0} \\
Z\end{array}$ & 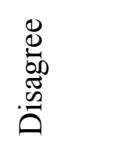 & 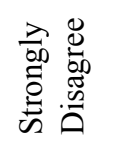 & $\stackrel{\mathbb{E}^{ \pm}}{\Sigma}$ & ت己 & 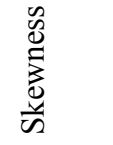 & 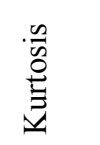 \\
\hline $\begin{array}{l}\text { Female students are driven to } \\
\text { outperform males in order to break } \\
\text { into what was traditionally } \\
\text { considered male occupation. }\end{array}$ & $26.4 \%$ & $24.7 \%$ & $31.9 \%$ & $9.4 \%$ & $7.7 \%$ & 3.53 & 1.195 & -0.444 & -0.568 \\
\hline $\begin{array}{l}\text { Female students are more success } \\
\text { driven and career motivated than } \\
\text { males. }\end{array}$ & $21.3 \%$ & $24.4 \%$ & $29.9 \%$ & $15.1 \%$ & $9.3 \%$ & 3.33 & 1.230 & -0.266 & -0.828 \\
\hline $\begin{array}{l}\text { Female students have greater } \\
\text { quantitative aptitude than males i.e. } \\
\text { good at maths. }\end{array}$ & $6.9 \%$ & $6.9 \%$ & $43.3 \%$ & $25.1 \%$ & $17.7 \%$ & 2.60 & 1.073 & 0.316 & -0.131 \\
\hline $\begin{array}{l}\text { Female students attend more } \\
\text { classes and tutorials than male } \\
\text { students. }\end{array}$ & $47.1 \%$ & $31.8 \%$ & $14.4 \%$ & $4.3 \%$ & $2.4 \%$ & 4.17 & .988 & -1.216 & 1.103 \\
\hline $\begin{array}{l}\text { Instructors perceive female students } \\
\text { as being more outstanding than } \\
\text { males and hence tend to favour } \\
\text { them in some ways. }\end{array}$ & $8.9 \%$ & $10.8 \%$ & $29.2 \%$ & $26.8 \%$ & $24.4 \%$ & 2.53 & 1.220 & 0.443 & -0.643 \\
\hline $\begin{array}{l}\text { Female students have more positive } \\
\text { attitude towards accounting than } \\
\text { males. }\end{array}$ & $19.5 \%$ & $24.8 \%$ & $36.3 \%$ & $13.5 \%$ & $6.0 \%$ & 3.38 & 1.122 & -0.218 & -0.579 \\
\hline $\begin{array}{l}\text { Female students in universities, } \\
\text { though in same age like males, } \\
\text { mature early and become more } \\
\text { serious with their studies than } \\
\text { males. }\end{array}$ & $25.4 \%$ & $25.8 \%$ & $29.4 \%$ & $12.7 \%$ & $6.7 \%$ & 3.50 & 1.190 & -0.385 & -0.694 \\
\hline $\begin{array}{l}\text { Female students are more } \\
\text { passionate about the accounting } \\
\text { profession than males. }\end{array}$ & $19.4 \%$ & $22.8 \%$ & $35.3 \%$ & $15.8 \%$ & $6.7 \%$ & 3.32 & 1.153 & -0.155 & -0.706 \\
\hline $\begin{array}{l}\text { Female students are less engaged in } \\
\text { extracurricular activities, they } \\
\text { therefore have extra time to study } \\
\text { than males. }\end{array}$ & $12.5 \%$ & $25.2 \%$ & $32.9 \%$ & $18.7 \%$ & $10.8 \%$ & 3.10 & 1.167 & -0.128 & -0.743 \\
\hline $\begin{array}{l}\text { Female students participate more in } \\
\text { class and are ready to share in } \\
\text { group discussion than male } \\
\text { students. }\end{array}$ & $25.9 \%$ & $28.5 \%$ & $27.3 \%$ & $11.3 \%$ & $7.0 \%$ & 3.55 & 1.188 & -0.486 & -0.583 \\
\hline $\begin{array}{l}\text { Accounting is more of feminine } \\
\text { career than masculine career. }\end{array}$ & $9.8 \%$ & $12.0 \%$ & $33.3 \%$ & $20.8 \%$ & $24.2 \%$ & 2.62 & 1.245 & 0.291 & -0.788 \\
\hline $\begin{array}{l}\text { Females students tend to seek } \\
\text { guidance from lecturer about how } \\
\text { to focus their energies to achieve } \\
\text { excellent grades than male students. }\end{array}$ & $29.2 \%$ & $30.6 \%$ & $30.6 \%$ & $6.2 \%$ & $3.3 \%$ & 3.76 & 1.046 & -0.546 & -0.186 \\
\hline $\begin{array}{l}\text { Female students are combining the } \\
\text { "understanding" and "performance" } \\
\text { driven approaches to accounting } \\
\text { examination better than male } \\
\text { students. }\end{array}$ & $12.2 \%$ & $18.5 \%$ & $48.4 \%$ & $13.2 \%$ & $7.7 \%$ & 3.14 & 1.046 & -0.050 & -0.138 \\
\hline $\begin{array}{l}\text { Recent gender activism has } \\
\text { favoured females more than males. }\end{array}$ & $14.6 \%$ & $18.2 \%$ & $30.7 \%$ & $19.4 \%$ & $17.0 \%$ & 2.94 & 1.282 & 0.044 & -0.977 \\
\hline
\end{tabular}


In addition, $54 \%$ of respondents with a mean score of 3.55 concurred that female students' class participation and readiness to share during group discussions give them leverage to outperform their male counterparts. Just above half of respondents $(51 \%)$ agreed that female student perform better because they work harder in order to break into accounting profession which was originally considered males' occupation. The same percentage of respondents $(51 \%)$ concurred that female students perform better because they mature earlier and become more serious with their studies than male students. These findings concur with explanations of Younger, Warrington and Williams (1999) who attributed girls' better grades in GCSE to their increased maturity and more effective learning strategies.

Only $46 \%$ of respondents were of the view that females achieved better grades in accounting examinations because they are more success driven and career motivated than males. Slightly this finding agrees with Mutchlers et al (1987)'s inferences that women are outperforming men because they are more success driven and career motivated than males. On whether females do better in accounting because of their positive attitude towards the discipline, only $44 \%$ of respondents agreed with the statement. Regarding whether females outperform men because they are passionate about the accounting profession, as suggested by Kumar (2010), only $42 \%$ of respondents thought this was true. Above one third of students (around 36\%) did not like to commit themselves concerning females' positive attitude and passion towards accounting.

Interestingly, only $38 \%$ of respondents were of the opinion that females perform better because they are engaged in less extracurricular activities than males. However, $33 \%$ of them could not commit themselves on this factor. While one third of respondents agreed that the contemporary gender activism which seems to favour females more has contributed to the higher performance of females in accounting subjects, $36 \%$ of them rejected the idea. On whether the perception of accounting as a feminine than masculine career could be contributing to females' over performance, $45 \%$ of respondents disagreed and one third of them could not commit themselves.

\subsection{Views per Gender Group}

Another objective of this study was to establish whether females' views regarding the factors contributing to females' better performance differ from those of males. Table 3 depicts that comparison. From Table 3 it is clear that female respondents were more agreeable to most of the statements than males. In all statements, except in three, females had higher mean scores of above 3.6 in most of the statements. In the three statements where females reflected lesser mean scores than men it appears they were displaying defence mechanism. These are the statements which suggest that females are favoured by instructors because of their outstanding performance, have more time to study due to the lesser involvement in extracurricular activities and gender activism favour them more than males. While $62 \%$ of females disagreed with the statement which suggested that their academic achievement may be influenced by instructors' perception of them being an outstanding group and therefore according them special favours (mean $=2.24$ ), only $32 \%$ of males disagreed with the statement $($ mean $=3.05$ ). This shows a wide division in perceptions among students as to how the instructor relates with them. Instructors need to be aware of this phenomenon as it may impact on how males approach their studies.

Table 3. Comparison of genders' opinions regarding factors causing females to outperform males

\begin{tabular}{|c|c|c|c|c|c|c|}
\hline \multirow[b]{2}{*}{ Factors } & \multicolumn{2}{|c|}{ Females } & \multicolumn{2}{|c|}{ Males } & \multicolumn{2}{|c|}{$\begin{array}{l}t \text { test for equality of } \\
\text { means }\end{array}$} \\
\hline & Mean & $\begin{array}{c}\text { Std. } \\
\text { Deviation }\end{array}$ & Mean & $\begin{array}{c}\text { Std. } \\
\text { Deviation }\end{array}$ & t-value & p-value \\
\hline $\begin{array}{l}\text { Female students are driven to outperform males } \\
\text { in order to break into what was traditionally } \\
\text { considered male occupation. }\end{array}$ & 3.79 & 1.144 & 3.05 & 1.135 & -6.413 & 0.001 \\
\hline $\begin{array}{l}\text { Female students are more success driven and } \\
\text { career motivated than males. }\end{array}$ & 3.72 & 1.078 & 2.62 & 1.171 & -9.691 & 0.001 \\
\hline $\begin{array}{l}\text { Female students have greater quantitative } \\
\text { aptitude than males i.e. good at maths. }\end{array}$ & 2.92 & 0.980 & 2.03 & 0.993 & -8.902 & 0.001 \\
\hline $\begin{array}{l}\text { Female students attend more classes and } \\
\text { tutorials than males. }\end{array}$ & 4.32 & 0.865 & 3.90 & 1.132 & -3.0942 & 0.001 \\
\hline $\begin{array}{l}\text { Instructors perceive female students as being } \\
\text { more outstanding than males and hence tend to }\end{array}$ & 2.24 & 1.158 & 3.05 & 1.159 & 6.809 & 0.001 \\
\hline
\end{tabular}


favour them in some ways.

Female students have more positive attitude towards accounting than males.

Female students in universities, though in same age like males, mature early and become more serious with their studies than males.

Female students are more passionate about the accounting profession males.

Female students are less engaged in extracurricular activities, they therefore have extra time to study than males.

Female students participate more in class and are ready to share in group discussion than males.

Accounting is more of feminine career than masculine career.

Females students tend to seek guidance from lecturer about how to focus their energies to achieve excellent grades than males.

Female students are combining the

"understanding" and "performance" driven approaches to accounting examination better than males.

Recent gender activism has favoured females more than males.

$\begin{array}{llllll}3.59 & 1.041 & 3.01 & 1.165 & -5.262 & 0.001 \\ 3.72 & 1.147 & 3.12 & 1.174 & -5.052 & 0.001 \\ & & & & & \\ 3.61 & 1.072 & 2.8 & 1.112 & -7.341 & 0.001 \\ 2.98 & 1.156 & 3.31 & 1.162 & 2.766 & 0.006 \\ & & & & & \\ 3.62 & 1.121 & 3.42 & 1.294 & -1.626 & 0.105 \\ & & & & & \\ 2.73 & 1.202 & 2.44 & 1.301 & -2.260 & 0.025 \\ 3.8 & 1.016 & 3.68 & 1.097 & -1.109 & 0.268 \\ & & & & & \\ 3.37 & 0.973 & 2.73 & 1.050 & -6.271 & 0.001 \\ & & & & & \\ & & & & & \\ 2.78 & 1.271 & 3.24 & 1.253 & 3.552 & 0.001\end{array}$

Only $33 \%$ of female respondents were of the view that their superior performance is caused by their less involvement in extracurricular activities (mean $=2.98$ ), but $46 \%$ of male respondents thought that that was case (mean $=3.31$ ). Whereas $41 \%$ of females respondents disagreed that gender activism favour them and impact on their academic achievement (mean $=2.78), 43 \%$ of males agreed (mean=3.24\%). Although around $30 \%$ of each gender group was uncertain about this statement, males were more likely to agree with it while females were more likely to disagree with it.

Although $22 \%$ of each sex agreed that considering accounting as more of the feminine career than masculine career could be influencing females to perform better in accounting, more males $-54 \%$ as compared to $40 \%$ disagreed with such belief. Large mean differences of above 0.80 were found on the following statements: "female students are more success driven and career motivated than males"; "female students have greater quantitative aptitude than males"; "female students are more passionate about the accounting profession than male students";"instructors perceive female students as being more outstanding than males and hence tend to favour them in some ways". Male respondents were more likely to disagree with all of these statements than females except on the instructors' perception concerning the smartness of females, where males were more agreeable to the statement.

The t-test for the equality of means shows a significant difference in means of sexes at $1 \%$ level of significance in all the statements except in three statements which are: "Female students participate more in class and are ready to share in group discussion than male students" $(p=0.105)$; "Accounting is more of feminine career than masculine career" $(p=0.025)$ and "Females students tend to seek guidance from lecturers about how to focus their energies to achieve excellent grades than male students" $(p=0.268)$. It should be noted that the difference in means between sexes on the statement "Accounting is more of feminine career than masculine career" is significant at $5 \%$ level of significance.

\subsection{Views per Year of Study}

Table 4 reflects the comparison of views of respondents from each year of study concerning factors contributing to better performance of females in accounting examinations. 
Table 4. Views of students in each year of study regarding factors causing females to outperform males

\begin{tabular}{|c|c|c|c|c|c|c|c|c|}
\hline \multirow[b]{2}{*}{ Factors } & \multicolumn{2}{|l|}{ Year 2} & \multicolumn{2}{|l|}{ Year 3} & \multicolumn{2}{|l|}{ Year 4} & \multicolumn{2}{|l|}{ ANOVA } \\
\hline & Mean & $\begin{array}{l}\text { Std. } \\
\text { Deviation }\end{array}$ & Mean & $\begin{array}{l}\text { Std. } \\
\text { Deviation }\end{array}$ & Mean & $\begin{array}{l}\text { Std. } \\
\text { Deviation }\end{array}$ & $\mathrm{F}$ & Sig. \\
\hline $\begin{array}{l}\text { Female students are driven to } \\
\text { outperform males in order to } \\
\text { break into what was traditionally } \\
\text { considered male occupation. }\end{array}$ & 3.52 & 1.109 & 3.49 & 1.288 & 3.56 & 1.195 & .116 & .890 \\
\hline $\begin{array}{l}\text { Female students are more success } \\
\text { driven and career motivated than } \\
\text { males. }\end{array}$ & 3.32 & 1.163 & 3.45 & 1.342 & 3.25 & 1.191 & .974 & .378 \\
\hline $\begin{array}{l}\text { Female students have greater } \\
\text { quantitative aptitude than males } \\
\text { i.e. good at maths. }\end{array}$ & 2.50 & 1.043 & 2.51 & 0.970 & 2.77 & 1.160 & 3.111 & .046 \\
\hline $\begin{array}{l}\text { Female students attend more } \\
\text { classes and tutorials than males. }\end{array}$ & 4.13 & 1.003 & 4.33 & 0.828 & 4.08 & 1.080 & 2.320 & .100 \\
\hline $\begin{array}{l}\text { Instructors perceive female } \\
\text { students as being more } \\
\text { outstanding than males and hence } \\
\text { tend to favour them in some } \\
\text { ways. }\end{array}$ & 2.32 & 1.157 & 2.73 & 1.280 & 2.55 & 1.201 & 3.794 & .023 \\
\hline $\begin{array}{l}\text { Female students have more } \\
\text { positive attitude towards } \\
\text { accounting than males }\end{array}$ & 3.34 & 1.070 & 3.57 & 1.099 & 3.26 & 1.170 & 2.780 & .063 \\
\hline $\begin{array}{l}\text { Female students in universities, } \\
\text { though in same age like males, } \\
\text { mature early and become more } \\
\text { serious with their studies than } \\
\text { males. }\end{array}$ & 3.35 & 1.142 & 3.7 & 1.119 & 3.48 & 1.269 & 2.887 & .057 \\
\hline $\begin{array}{l}\text { Female students are more } \\
\text { passionate about the accounting } \\
\text { profession males. }\end{array}$ & 3.4 & 1.080 & 3.36 & 1.156 & 3.23 & 1.212 & .854 & .426 \\
\hline $\begin{array}{l}\text { Female students are less engaged } \\
\text { in extracurricular activities, they } \\
\text { therefore have extra time to study } \\
\text { than males. }\end{array}$ & 3.07 & 1.094 & 3.23 & 1.186 & 3.02 & 1.211 & 1.232 & .293 \\
\hline $\begin{array}{l}\text { Female students participate more } \\
\text { in class and are ready to share in } \\
\text { group discussion than males. }\end{array}$ & 3.59 & 1.088 & 3.78 & 1.186 & 3.33 & 1.241 & 5.095 & .007 \\
\hline $\begin{array}{l}\text { Accounting is more of feminine } \\
\text { career than masculine career. }\end{array}$ & 2.78 & 1.220 & 2.51 & 1.238 & 2.59 & 1.266 & 1.657 & .192 \\
\hline $\begin{array}{l}\text { Female students tend to seek } \\
\text { guidance from lecturer about how } \\
\text { to focus their energies to achieve } \\
\text { excellent grades than males. }\end{array}$ & 3.63 & 1.077 & 4.10 & 0.962 & 3.60 & 1.024 & 10.124 & .000 \\
\hline $\begin{array}{l}\text { Female students are combining } \\
\text { the "understanding" and } \\
\text { "performance" driven approaches } \\
\text { to accounting examination better } \\
\text { than male students. }\end{array}$ & 3.13 & 1.007 & 3.21 & 1.090 & 3.11 & 1.047 & .332 & .718 \\
\hline $\begin{array}{l}\text { Recent gender activism has } \\
\text { favoured females more than } \\
\text { males. }\end{array}$ & 2.80 & 1.273 & 3.09 & 1.315 & 2.94 & 1.257 & 1.654 & .193 \\
\hline
\end{tabular}


Table 4 shows that third year students had the highest mean scores in 10 out of 14 statements and second and fourth year students each had the highest scores in 2 statements. Respondents in all years of study had their highest mean scores of above 4 on a statement: "female students attend more classes and tutorials than male students" with third year registering the highest mean score of 4.33.This implies that students at all levels under study concur with findings of prior studies, for example that of Wainer and Steinberg (1992) who found that females perform better because they attend classes more often than their male counterparts. Other researchers like Devadoss and Foltz (1996) also reported a positive relationship between class attendance and students' academic attainment. Second year students had the highest scores among the three years on statements: "female students are more passionate about the accounting profession than males" (mean =3.40) and "accounting is more of a feminine career than masculine career" (mean $=2.78$ ). Fourth year respondents had the highest mean scores in statements suggesting that female students are driven to outperform males in order to break into what was traditionally considered male occupation (mean $=3.56$ ) and female students have greater quantitative aptitude than males (mean =2.77).

The statements which received the overall lowest and second lowest means scores (mean $=2.53$ and mean $=2.60)$ were largely contributed to by second year students who were the least to believe in statements which proposed that instructors perceive female students as being more outstanding than males and hence tend to favour them in some ways $($ mean $=2.32)$ and that female students have greater quantitative aptitude than males (mean $=2.50$ ). The first and second overall highest mean scores (mean $=4.17$ and mean $=3.76$ ) were greatly contributed to by third year students who were more likely to believe that females' superior academic achievement is caused by their more often class attendance (mean $=4.33$ ) and their frequent consultancies on how to focus their energies to achieve excellent grades (mean $=4.10)$.

The one-way analysis of variances (ANOVA) revealed that the differences of means between the three years of study were significant in four statements at 0.05 significance level. These were: "female students have greater quantitative aptitude than males" and "instructors perceive female students as being more outstanding than males and hence tend to favour them in some ways". In both statements the means were below 3 the median of the Likert scale used to rank the opinions of students, which means that students from all years of study were less likely to agree with these statements. However, the second year students were more likely to disagree with statement implying favourable instructors' perception towards females than the other years. Other statements which indicated a significant difference in scores were: "female students participate more in class and are ready to share in group discussion than male students" and "female students tend to seek guidance from lecturers about how to focus their energies to achieve excellent grades than male students". Although students from the three years of study tend to agree with these statements, the third year students were more agreeable than the rest, particularly regarding female students' habit of seeking guidance from lecturers on how to succeed in academic work. It is not clear why third year students appeared to be more positive towards the research statements than others.

\subsection{Analysis of Qualitative Questions}

One of the questions asked the respondents to suggest other factors contributing to differences in academic performance between female and male students. Out of 418 students only 176 of them gave their opinions on this question. Most respondents (76 out of 176, 45\%) seemed to agree that females' superior performance is due to their hard work which is induced by factors like having more responsibilities at home, drive for self-sufficiency, and competition among themselves. Respondents argue that females' hard working habits are exhibited in frequent class attendance, asking questions inside and outside class, making study plans and adhering to them and forming study groups. The following statements are some of the explanations why female students work harder: "Due to the high levels of divorce rates, a woman must be able to stand on her own feet at any time, hence the need for a good education and job". "Females want to be more emancipated in modern times which drive them to work harder because men are no longer the sole provider for the family". These statements signal how crucial the social factors are on academic attainment.

A good number of respondents (54 out 176, 31\%) blame the underperformance of male students on their failure to exert necessary efforts to their studies. Respondents characterized males with allowing social life to have upper hand while at schools. Involvement in heavy drinking and other entertainment activities, poor class attendance, negative attitude towards studies, lack of practice, waiting until too late to study, studying only for passing examinations instead of understanding, and failure to seek assistance from lecturers and colleagues were mentioned as factors that hamper male students' performance. According to respondents of this study it appears the "macho" behaviour described by Warrington, Younger, and Williams (2000) could be associated with male accounting students at the University of Botswana. Male students' lack of seriousness towards their studies was summarized by one female student in the following words: "Males dodge lessons, prefer to sit at the back and 
make noise, work on their laptops during lessons (surf the net), some have a tendency of perpetually leaving class during the course of the lesson to answer their phones".

What emerged from 176 responses which were given to this question was that academic performance is the function of an individual's commitment and determination to succeed. This was categorically asserted by 14 out of 176 responses $(8 \%)$ which disclosed that gender does not determine academic success but rather one's commitment, perseverance and right attitude towards learning. This is in agreement with various scholars who have attributed academic achievement to personal effort (e.g. Carbonaro, 2005; Eskew \& Faley, 1988).

Another open-ended question sought the views of respondents regarding what should be done to bridge the performance gap between females and male students in accounting examinations. Out of 256 respondents to this question 92 of them (36\%) suggested that male students should be encouraged to take their accounting studies seriously. They should be persuaded to attend classes and tutorials more often, participate in class discussion, form study groups, have study plans and stick to them, go for consultations and reduce social activities which deprive them the studying time.

A quarter of students who commented on this question were of the view that both genders need to be equally motivated to do better in their studies. Along these thoughts, respondents proposed that students should be encouraged to work in gender balanced groups, class and tutorial attendance should be monitored and career guidance and counselling should be intensified. About $13 \%$ of respondents to this question had a view that nothing can be done to reduce academic performance gap between gender other than individual's commitment and positive attitude towards studies. A request for equitable treatment of both genders by lecturers was raised by $12 \%$ of respondents to this question. This group believe that female students outperform their male counterparts because they are favoured by lecturers. Regardless of whether these sentiments are true or not, the fact that they have been raised calls for an action from accounting educators. They should try to remove any signal that could be causing such believes. A small number of students (6 out of 256) suggested that motivational speakers from accounting profession should be invited by educational institutions to speak about prospects of working as an accountant. They believe this will inspire students, especially males who are believed to have tendency of underrating the accounting profession when compared with other professions such as medicine, engineering and computer sciences.

\section{Summary of Findings}

Regarding the overall students' opinion on factors contributing to females' superior performance, this study revealed that female students have better academic achievement because they attend more classes and tutorials, seek guidance on their studies from lecturers and participate more in class discussions than their male counter parts. Moreover, respondents agreed that female students excel in their academic performance because they work harder to break into historically male dominated accounting profession and they mature earlier and become more serious with their studies than male students.

Comparison of genders' views on why females perform better academically than males, reflected that females were more likely to agree than males that their superior performance is influenced by their regular class and tutorials attendance, their tendency to seek guidance on how to succeed and their drive to break into accounting career. In addition, females have more belief that they have better accomplishment because they mature early and are success driven, participate fully in class discussion, are passionate about accounting profession, and have the right attitude towards accounting.

Views from different years of study did not reflect big departure from what was already revealed in the overall and per gender analysis. However, in the areas where the differences were statistically significant fourth year students were more likely to agree that female students have greater quantitative aptitude than males. Third year students were more likely to agree that instructors perceive females as big achievers, females students participate more in class discussions and they tend to seek guidance from educators.

From this study the key factor explaining academic performance is believed to be individual's commitment and right attitude towards accounting studies. Respondents believe that female students perform better because they have better study ethics and male students perform poorly because they lack enthusiasm towards studies. Males fail to balance social life and academic work while at school.

The main suggested remedy to narrow the gap in academic performance was to encourage all students in general and males in particular to put more efforts in their academic work and have positive attitude towards accounting studies. Monitoring was mentioned as one of the measures to curb male's truancy behaviour. 


\section{Conclusion}

The findings of this study concur with findings of previous studies on gender differences in accounting performance that suggest that female students outperform their male counterparts because they work harder, have better study skills, attend classes regularly, and strike a good balance between their social life and academic life. The opposite is true with men. The implications of this study are that male students need to re-examine their attitude towards education, class attendance and participation in academic activities in order to improve their grades. The society which has a bearing on the upbringing of the boy child and the educational institutions which create the learning environment need to remain vigilant in ensuring that males remain focused on what matters in life.

As the world is witnessing the surging of females in education in terms of enrolment and achievement, educational authorities should be careful to avoid the recurring of gender imbalances in education which existed during the era when females were at the disadvantaged end. Gender inequality against males may have greater damaging consequences to labour markets, wage gaps, and social peace. Therefore, means of achieving balance in gender academic attainment should be sought. Further studies may focus on what can be done by the community and educational institutions to create gender equity through balanced gender academic performance.

\section{References}

Bagamery, B. D., Lasik, J. J., \& Nixon, D. R. (2005). Determinants of success on the ETS business major field exam for students in an undergraduate multisite regional university business programme. Journal of Education for Business, 81(1), 55-63. http://dx.doi.org/10.3200/JOEB.81.1.55-64

Baldwin, B. A., \& Howe, K. R. (1982). Secondary-level study of accounting and subsequent performance in the first college course. The Accounting Review, 57(3), 619- 626.

Benbow, C. P., \& Stanley, J. C. (1980). Sex differences in mathematical ability: Fact or artefact. Science, 210(12), 1262-1264. http://dx.doi.org/10.1126/science.7434028

Bergin, J. L. (1983). The effects of previous accounting study on student performance in the first college-level financial accounting course. Issues in Accounting Education, 1,19-28.

Black, H. T., \& Duhon, D. L. (2003). Evaluating and improving student achievement in business programmes; the effective use of standardised assessment tests. Journal of Education for Business, 79(2), 90-98. http://dx.doi.org/10.1080/08832320309599095

Brahmasrene, T., \& Whitten, D. (2001). Assessing success on the uniform CPA exam: A logit approach. Journal of Education for Business, 77(1), 45-50. http://dx.doi.org/10.1080/08832320109599670

Carbonaro, W. (2005). Tracking, Students' Effort, and Academic Achievement. Sociology of Education, 78(1), 27-49. http://dx.doi.org/10.1177/003804070507800102

Chung, J., \& Monroes, G. S. (1998). Gender differences in information processing: An empirical test of the hypothesis-confirming strategy in an audit context. Accounting and Finance, 38, 265-279. http://dx.doi.org/10.1111/1467-629X.00013

Colom, R., \& Lynn, R. (2004). Testing the development Theory of sex differences in intelligence on 12-18 Years olds. Personality and Individual Differences, 36, 75-82. http://dx.doi.org/10.1016/S0191-8869(03)00053-9

Dayioglu, M., \& Turut-Asik, S. (2004). Gender Differences in Academic Performance in a Large Public University in Turkey. Economic Research Centre Working Papers in Economics, 4(17), 1-34.

Delamont, S. (1999). Gender and the discourse of decision. Research papers in Education, 14(1), 3-21. http://dx.doi.org/10.1080/0267152990140102

Devadoss, S. B., \& Foltz, J. (1996). Evaluation of factors influencing students class attendance and performance. American Journal of Agricultural Economics, 78(3), 499-507. http://dx.doi.org/10.2307/1243268

Eskew, R. K., \& Faley, R. H. (1988). Some determinants of student performance in the first college-level of the financial accounting course. The Accounting Review, 63(1), 137-147.

Estronaut. (1999). Gender differences in cognitive ability. Retrieved May 25, 2012, from http://www.estronaut.com/a/gender_cognition.htm

Fraser, A. A., Lyttle, R., \& Stolle, C. (1978). Profile of Female accounting majors: Academic performance and behavioural characteristics. The Woman CPA, October, 18-21. 
Gallagher, T. (2001). Equal opportunities commission conference on boys and girls in the 21st Century: Gender Differences in Learning. Retrieved February 2, 2012, from http://www.eoc.org.hk/eoc/graphicsfolder/inforcenter/newsletter/content.aspx?itemid=4948

Gibb, S. J., Fergusson, D. M., \& Horwood, L. J. (2008). Gender differences in educational achievement to 25. Australian Journal of Education, 52(1), 63-80. http://dx.doi.org/10.1177/000494410805200105

Gracia, L., \& Jenkins, E. (2003). A quantitative exploration of student performance on an undergraduate accounting programme of study. Accounting Education, 12(1), 15-32. http://dx.doi.org/10.1080/0963928032000049375

Harding, S. G. (1986). The Science Question in Feminism, Cornell University Press, USA.

Hoffman, M., Gneezy, U., \& List, J. (2011). Nurture affects gender differences in spatial abilities. Proceedings of the National Academy of Sciences, 108(36). http://dx.doi.org/10.1073/pnas.1015182108

Jackling, B., \& Anderson, A. (1998). Study mode, general ability and performance in accounting: A research note, Accounting Education: An International Journal, 7(1), 65-73.

Kimura, D., \& Hampson, E. (1994). Cognitive pattern in men and women is influenced by fluctuations in sex hormones. Current Directions in Psychological Science, 3(2), 57-61. http://dx.doi.org/10.1111/1467-8721.ep10769964

Kumar K. S. (2010). Gender imbalance in Accounting Profession: Evidence from Botswana. The IUP Journal of Accounting and Research, 11(4), 42-53.

Lagerlöf, N. (1999). Gender Inequality, Fertility, and Growth. Mimeographed. Department of Economics, University of Sydney.

Leonard, D. K., \& Jiang, J. (1999). Gender Bias and the College Predictors of the SATs: A cry of Despair. Research in Higher education, 40, 375-407. http://dx.doi.org/10.1023/A:1018759308259

Lipe M. G. (1989). Further evidence on the performance of female versus male accounting students. Issues in Accounting Education, 4(1), 144-152.

Mackintosh, N. J. (1998). Reply to Lynn. Journal of Biosocial Sciences, 30, 533-539. http://dx.doi.org/10.1017/S0021932098005331

Mitchell, F. (1988). High school accounting and student performance in the first level university accounting course: A UK study. Journal of Accounting Education, 6(2), 279-291. http://dx.doi.org/10.1016/0748-5751(88)90009-7

Mutchler J. F., Turner J. H., \& Williams D. D. (1987). The performance of female versus male accounting students. Issues in Accounting Education, 12(1), 103-111.

Nasser, K., \& Peel, M. J. (1998). An exploratory study of the impact of intervening variables on student performance in a principles of accounting course. Accounting Education: an International Journal, 7(3), 209-223. http://dx.doi.org/10.1080/096392898331153

OECD. (2011). Report on the Gender Initiative: Gender Equality in Education, Employment and Entrepreneurship at the Meeting of the OECD Council at Ministerial Level, Paris, 25-26 May 2011.

Okafor C. A., \& Egbon, O. (2011). Academic Performance of male versus Female Accounting Undergraduate Students: Evidence from Nigeria. Higher Education Studies, 1(1), 9-19. http://dx.doi.org/10.5539/hes.v1n1p9

Pekkarinen T. (2012). Gender differences in education. Nordic Economic Policy Review, 1, 1-31.

Reddock, R. (2009). Gender and Achievement in Higher Education, Paper presented at Conference of the Association of Caribbean Higher Education Administrators (ACHEA), Port of Spain, Trinidad and Tobago.

Roos, S. (2009). Factors affecting Southern African students' success in CIMA examinations. Meditari Accountancy Research, 17(1), 49-67. http://dx.doi.org/10.1108/10222529200900004

Sheard, M. (2009). Hardiness, commitment, gender, and age differentiate university academic performance. British Journal of Educational Psychology, 79, 189-201. http://dx.doi.org/10.1348/000709908X304406

Steele, C. M. (1997). A threat in the air: How stereotype shape intellectual identity and performance. American Psychologist, 52(6), 613-629. http://dx.doi.org/10.1037/0003-066X.52.6.613 
Tyson, T. (1989). Grade performance in introductory accounting courses: Why female students outperform males. Issues in Accounting Education, 4(1),153-160.

University Council and General Board (2001). Indicators of Academic Performance: Notice. Retrieved February 1, 2012, from http://www.admin.cam.ac.uk/reporter/2002-03/weekly/5913/6.html

Wainer, H., \& Steinberg, L. S. (1992). Sex Differences in Performance on the Mathematics Section of the Scholastic Aptitude Test: A Bidirectional Validity Study. Harvard Educational Review, 62, 323-336.

Wally-Dima L., \& Mbekomize, C. J. (2010). Gender performance differences in accounting examinations: The case of the University of Botswana. The Journal of Finance and Management, 19(1), 55-61.

Warrington, M., Younger, M., \& Williams, J. (2000). Student Attitudes, Image and the Gender Gap. British Educational Research Journal, 26(3), 394-407. http://dx.doi.org/10.1080/01411920050030914

Wilberg, S., \& Lynn, R. (1999). Sex Differences in Historical Knowledge and School Grades: A 26 Nation $\begin{array}{llll}\text { Study. Personality and Individual Differences, } & \text { 27, }\end{array}$ http://dx.doi.org/10.1016/S0191-8869(99)00066-5

Wilkinson, H. (1994). No Turning Back: Generations and Gender quake. Demos, 1994, London, England.

Younger, M., Warrington, M., \& Williams, J. (1999). The gender gap and classroom interactions: Reality and Rhetoric? British Journal of Sociology of Education, 20, 325-341. http://dx.doi.org/10.1080/01425699995290

\section{Copyrights}

Copyright for this article is retained by the author(s), with first publication rights granted to the journal.

This is an open-access article distributed under the terms and conditions of the Creative Commons Attribution license (http://creativecommons.org/licenses/by/3.0/). 